\title{
The Ambiguity of Individual Gestures: Revisions of World War I in Abel Gance's J'accuse, Alain's Mars ou La guerre jugée, and Bertrand Tavernier's La vie et rien d'autre
}

Van Kelly

University of Kansas

\begin{abstract}
Alain, a combatant in World War I and eminent French pacifist during the 1920s and 1930s, was skeptical about official attempts to instill military esprit de corps and passion: "When you are faced with military ceremony, go away. If you are obliged to stay, think about the dead, count the dead" (Mars ou La guerre jugée [Mars or the Judgement of War], 257). ${ }^{1}$ Major Dellaplane, a protagonist in Bertrand Tavernier's 1989 film on the Great War, La vie et rien $d$ 'autre (Life and Nothing But), would agree. In the closing scenes, he revises his obsession with the 350,000 French soldiers from World War I still listed in 1920 as missing in action. Dellaplane, to the exasperation of his commanding general, Villerieux, who accuses him of being a maniac, scrupulously keeps files of the missing, based on military records but also on queries from those attempting to locate relatives who had served in the war to end all wars. His job, as long as the army tolerates his competence despite his obsession, is to ascertain the fate of as many MIAs as possible by identifying veterans stricken with amnesia, putting a name to those buried as unknown, or otherwise determining with a sleuth's skills of deduction the time and place of death of this soldier or that soldier.
\end{abstract}

At the end of the film, having retired from the French army, the former major refers one last time to the million-and-a-half French war dead and missing, when he "writes" a letter (in a voice-over) to Irène de Courtil, an aristocratic woman with whom he has fallen deeply in love while helping her ascertain the status of her husband, an MIA who, as it turns out, died in the war. Dellaplane displaces our angle from the number of missing and unidentified to the overall statistics of French war dead, and in so doing he echoes the touchstone ending of Abel Gance's interwar films, the silent and sound versions of J'accuse (That They May Live, released respectively in 1919 and 1938), where the protagonist Jean Diaz, in a feverish hallucination and apocalypse, witnesses the masses of dead soldiers rise from the Verdun battlefield so that their sacrifice not be forgotten by civilians. Says the first of the dead to 
resuscitate, in an intertitle of the silent version: "My friends, the time has come to know if our deaths have served a purpose! Let's go see if the people back home are worthy of our sacrifice. Rise up!" 2 In 1919, thanks to the filmmaker's use of a split screen, the throng of the returning dead marches homeward on a plane above documentary clips of the allied victory parade down the Champs-Elysees. Gance recreates the death march with the camera, montage, and intertitles ("Diaphanous and fantastically heroic ... a all the dead were on the road and the demented earth was becoming transparent beneath their steps"). Tavernier adopts a more distanced approach. The character Dellaplane speaks of the return of the dead, offering the audience only the soundtrack, a verbal rendition of his fantasy. We do not see the dead return:

This is the last time I will pester you with my terrible statistics, but by comparison with the time allied troops needed to march down the ChampsElysees during the victory parade-three hours, I believe-I calculated that, at the same speed and in the same formation, the procession of the piteous dead of that unforgivable madness would have lasted no fewer than eleven days and eleven nights. ${ }^{3}$

In contrast to Dellaplane, Gance's protagonist Diaz in both the silent and the sound endings of J'accuse is intent on, and succeeds in, resurrecting the dead temporarily. ${ }^{4}$ In 1919, or at least the much reduced 1922 version that remains from the lost silent original, Diaz is a poet suffering from battle fatigue and shellshock. $^{5}$ He returns to his native village Orneval and mysteriously sends out invitations for an evening where he puts the villagers on the spot: have they remembered the dead by living good lives in their absence? If so, they have nothing to fear, but he has actually seen their dead: "They had earth-stained faces and eyes full of stars. They came innumerable from the far horizon, like roused waves." In the end, Jean accuses the civilians of amatory infidelity and profiteering: they have disgraced their kin and fellow citizens who died to protect France from the Teutons, represented as the war aggressors. Diaz warns the crowd that the dead are approaching to demand an accounting: "Don't you hear, there on the north wind, millions of death rattles crying to you in agony: 'I accuse! I accuse! I accuse!'?' The presence of the dead outside the door is no surprise to the spectators, who have been privy to their march from northern France, filmed spectacularly by Gance and his cameramen, Burel, Bujard, and Foster. ${ }^{6}$ Historian Jay Winter estimates that one to two million people saw the silent film and the eventual return of the cross-carrying dead to their tombs, and it is no exaggeration to say that through his silent versions of J'accuse, which symbolized an instinctive French reaction against the violence and slaughter, Gance acquired significant influence on contemporary French attitudes toward war and peace, much as Alain did with his postwar essays in the pages of the review Libres propos and with the 1921 and 1936 editions of his book, Mars ou La guerre jugée. When Gance later used the leverage of his earlier successes in silent film to finance a sound version of $J$ 'accuse, he extensively revised the scenario and adapted it to the new and different threats of war that hung over Europe in 19371938. 
Alain's admonition, Diaz's eschatological kerygma (or preaching of the pacifist gospel), and Dellaplane's precision project different lights on WWI despite their shared reliance on strategies of counting to convey an antiwar message. Alain and Tavernier, moreover, with their sober treatment of WWI, provide counterpoints to Gance's sensationalism which nevertheless represents quite accurately a major aspect of French interwar sensibilities. As Winter has shown in his study of collective mourning in WWI, the traditional elegiac theme of the return of the dead was a common theme of the soldierly and popular imaginary during the war and in the interwar period, and Gance's silent film reflects an era where the proximity of death encouraged belief in the uncanny and the supernatural. ${ }^{7}$ Maurice Barres popularized the legend of the resurrection of the dead as reinforcements against the Germans at the battle of Bois-Brûle, and soldiers reported the reappearance of dead comrades and telepathic communication frequently enough to convince the French army to commission an official study. Winter describes a meeting of civilian "spiritualists" at the Père Lachaise cemetery on 31 March 1918, prior to the release of Gance's film, where "fallen soldiers joined the ceremony." 8 A genre, psychic or spirit photography, which purported to photograph crowds of ghosts encircling public memorial ceremonies, was quite popular. All these elements give a more precise context to Gance's filmic return of the dead in the silent $J^{\text {'accuse, }}{ }^{9}$ a context that is not as divorced as it seems from the understatement of Alain's mental roll call.

By contrast with both Gance and Alain, Tavernier's distance from the atmosphere of the times permits him to conceive of a psychological resolution for Dellaplane's obsessive counting: at the end of the film, after he has resigned from the army and made one last count of the dead, he turns to the pursuit of Irène's love. Jean Cosmos, who wrote the scenario for La vie et rien d'autre, indicates that he and Tavernier sought not so much to create a documentary on WWI and its 350,000 MIAs, but to make a statement against the ambient pessimism about the state of the world in the late 1980s: "The true goal was . . to tell a love story, that is, a story of hope. And at the same time, show that positive forces . . . are not doomed to failure in the pact they have to maintain against the opposing, negative forces." ${ }^{\prime 10}$ The insistence that catastrophes are not predetermined echoes Alain: "the most dangerous opinion is precisely the one that would lead us to believe war is imminent and unavoidable" (Mars, 230). Alain's goal, nevertheless, like Gance's, was militant and pressing: prevent a second world war. Tavernier's is more personal than political, given the final turn toward love, and La vie et rien $d$ 'autre lacks the ideological urgency (though not the humanitarian appeal) implicit in J'accuse and in Mars ou La guerre jugée. As Cosmos says, WWI is only indirectly present in $L a$ vie et rien d'autre as so many "visible and widespread scars on the earth, on the trees, on the bodies of men," since the film's action occurs in 1920, after the conflict. ${ }^{11}$ In marked contrast, Gance and Alain represent 1914-1918 as both aftereffect of the conflict and as pacifist tactic for the immediate postwar.

In my arguments, I will focus on the shifting sense of antiwar gestures between the earlier and later versions of Gance's archetypal cinematographic depiction of WWI, J'accuse, concentrating especially on the light that French pacifism from 
1919 to 1938 casts on the filmmaker's endeavors. Many (though certainly not all) of the outrageous filmic excesses with which critics reproach Gance mirror in fact interwar French political culture. Alain's remarks in Mars ou La guerre jugée and Roger Martin du Gard's foregrounding of the pacifist character Jacques in his interwar epic novel Les Thibault (crucial volumes of which were published in 1936) will furnish a comparative gloss of the aims and efficacy of Gance's pacifism and will help situate $J$ 'accuse as one of the major interwar treatments of war and peace. As Tavernier's retrospective on WWI shows, however, it is still imperative to count the dead once the catastrophe has been distanced. The eyewitness memory of WWI has faded, though not perhaps the lessons it can teach, so I will conclude with a brief return to Tavernier and to the Great War as it is viewed today.

\section{Silent and Sound Versions of Gance's J'accuse}

Gance's scene from the silent J'accuse, where the dead slowly rise from the battlefield one-by-one and then in mass, is easily the film's touchstone, but the Pathe Frères synopsis that individual theaters printed in their programs for the long, three-episode version of 1919 hardly mentions the scene. The description is sibylline, probably to assure surprise among the audience: Diaz "has terrible visions that sow panic in the village." 12 The landscape, a devastated, desertlike plain surrounded by large framing hills in the distance, dotted with the cadavers of those fallen in battle, suggests the otherworld but without redemption. The throngs of the dead and missing-not Tavernier's 1,500,000, but certainly plethoric-are condemned to wander without sepulcher in search of vindication and remembrance. Once they witness the fear they inspire among the thankless, ungrateful living who have acted conveniently as if the war entailed no human sacrifice, they return to their graves. In the sound remake of 1938, the landscape for the return of the dead is furnished differently, by the imposing anthropomorphic tower of the ossuary at Douaumont whose ominous flashing scowl keeps watch over the dead of the battle of Verdun and complements the superimposed images of soldiers who had survived the war but with piteous facial deformities. An officer from the French army, Colonel Picot, had organized these war invalids into the Fédération nationale des trépanés et mutiles de face (National Federation of the Trepanned and Facially Wounded Soldiers), known for short as the Gueules Cassees, or Broken Faces. ${ }^{13}$ The group militated against civilian forgetfulness of 1914-1918. The return of the dead in the silent version also included such war invalids in its cast, but they completely dominate the final moments of the 1938 sound version where they are shown individually, one after the other, in prolonged close-ups. ${ }^{14}$ In both films, nevertheless, the appearance of the dead is woven primarily into a mythical scheme rather than a naturalistic one. ${ }^{15}$

The war dead wander back to their graves, leaving a debilitated Diaz to die in the last scene of the silent film, but not before the child, little Angele, has guided his hand to write, one last time, "I accuse," in an inverted school lesson where the student serves as schoolmaster, having absorbed the lessons of the Great War: 
caused by Germanic aggression and brutality, the home front nevertheless forgets those who defended France, and the noble idealism of the soldier goes unrewarded. I will return to the pacifist undertones of this concluding scene in a moment, but as Alan Williams says, Gance has the curious profile of a "pacifist nationalist," 16 and a quotation from a Pathé Frères advertising flyer for the 1919 $J$ 'accuse accentuates the patriotic aspect of Gance's screen message: “" J'ACCUSE" is a man's cry against sabre-rattling, an "objective" and triumphant cry against German militarism and its assassination of civilized Europe."17 In the scenario for the original, long version, there is even a virulent, international trial of the German war crimes and aggression, which evokes anachronistic shades of Nuremburg, ${ }^{18}$ and it is indeed curious that the filmmaker insisted his work would be popular on the screens of the Central Powers after the war. ${ }^{19}$ Although Icart asserts that Gance produced the shortened 1922 version "better to exalt the pacifist aspects of the work, [and] permit it to continue to be shown with success, above all across the borders," ${ }^{20}$ the single-episode, silent $J$ 'accuse retains the antiGerman, French patriotic perspective that characterized the longer original. Edith, wife of Diaz's fellow soldier and rival, François Laurin, is raped by Germans in the Ardennes and taken captive. She gives birth to little Angele, whom Diaz protects. The rape scene, played out in shadows with the Prussian spiked helmet figuring prominently, stands for the political aggression denounced in the film's opening scene when actual units of the Allied armies (including American and French colonial troops) take up a formation that spells out in capitals J'ACCUSE. A phantom Gallic warrior makes his appearance on the battlefield to spur on the French offensive against the Germans.

Norman King, speaking about the silent $J$ 'accuse, states that "the ultimate question is not whether the slaughter should have been avoided but whether it has served a purpose," 21 an evaluation that Richard Abel's remarks complement: "Seemingly critical of a patriotism that blindly ignores the death it causes, [the silent film] J'accuse ends up celebrating the dead's sacrifice as a form of patriotism" (302). ${ }^{22}$ The moral and political lessons were, for Gance's public, doubled by an anagogical one, to be sure: do not be like the French depicted in Diaz's hometown, do not forget the dead, honor their sacrifice which repulsed the invader. Gance's efforts to incriminate the French war effort itself are present but lukewarm. Implicitly, French revenge motives are condemned in his denunciation of the war fever and moral blindness of the generation of 1870, represented in the person of Maria-Lazare, Edith's ultrapatriotic father who covets the outbreak of war in 1914 as the chance to retake Alsace-Lorraine.

The last intervention of little Angèle, as the character who inherits the spirit of Jean Diaz by helping him write on the black school slate the film's last "J'accuse!," can also be read more simply, not as an outright expression of nationalism but as a pacifist construction: do not let a future war kill this child. In contrast to the xenophobic elements in the film, the action is punctuated by shots of the manuscript of Jean Diaz's book of poems, Les pacifiques (The peaceful), and Gance does not hesitate to show, through the death of François Laurin (Lorrain?) and the progressive debilitation of Diaz under artillery bombardment, the brutal effects of trench warfare. Other intertitles in the film also convey an 
antiwar message, such as the quotation from a contemporary work, Lettres diun soldat (Letters from a Soldier): "The weather is nice and the morning indifferent. The dead will not bother springtime." ${ }^{23}$ The accusations against war serve elegiac ends, however, rather than political ones, except for the anti-German elements which were perhaps accentuated by Gance because of the aid he received from the French army in filming the battle scenes. ${ }^{24}$ The film's ultimate scenes pointedly refocus the viewer's attention on the manuscript of Les pacifiques, which Diaz, who has lost his sense of identity, stumbles upon just before his death. Intertitles inform us that "the soldier in him had killed the poet, and he laughed at that lunatic who, earlier, had written verses on sunny peace and the sweetness of life." He tears up his manuscript, but hesitates when he arrives at the page bearing the poem "Hymn to the Sun." This provokes him to improvise several alexandrines, just before he dies: "I used to call myself Jean Diaz, but I've changed my muse, / My former sweet name has become 'I accuse'!" He then adds a coda, inscribed against the bucolic view of life purveyed in "Hymn to the Sun": "And I accuse you, Sun!...of having lit the horrible epic . . quietly, placidly, without disgust." Elegy merges with accusation, and one is left with more of a mixed pacifist and nationalist agenda by the end of the shortened film. The documentary scenes of the victory parade down the Champs Elysées, which in fact was led by soldiers who had been disfigured, the mutiles de guerre, ${ }^{25}$ can be seen as a demand that the sacrifice of the French war dead, whose death march homeward is viewed simultaneously on the split screen, not be met with civilian indifference. Even in this technically spectacular finale of the reduced-length silent version, where the documentary and the imaginary divide the screen, it is not clear that the filmmaker's pacifism overrides his patriotism, though Diaz's death in the very last moments, staged as the unfortunate dashing of the sentiments expressed in Les pacifiques, is a strong reminder of the antiwar sentiment that at the very least haunts the work. ${ }^{26}$

The 1938 sound remake of J'accuse altered the original scenario considerably, while retaining the eschatological ending that suggested the resurrection of the dead for a last judgment. Diaz is no longer a poet but an expert scientific glassmaker. He has a heroic, near-death experience in WWI, when, on the very eve of armistice, he volunteers for the last patrol toward the German lines and miraculously lives through the experience, the sole survivor among all his comrades including Laurin. ${ }^{27}$ Soon after the war, Diaz discovers a formula for verre d'acier, or steel glass, the qualities of which make it a perfect defensive arm against grenades and thousands of bullets. ${ }^{28}$ His desire to prevent another war, that is, to assure that WWI lived up to its moniker of the Last War, la der des der, finds in this sci-fi formula a technological vehicle for pacifism. If bullets can no longer kill, nonaggressors can turn the other cheek with impunity and cut future wars short. Henri Chimay, now the owner of the industrial glassworks where Diaz did the research that led to the discovery of verre diacier, turns the inventor's formula to different uses once Diaz becomes catatonic due to movement of shrapnel still left in his head from the wound that almost killed him on the last patrol. Chimay realizes that Diaz's magic shield can also be used to enhance the French army's offensive capabilities, indeed to make it invincible, so 
he furthers his political career by making it available to the government. Not entirely by coincidence, Chimay also was the captain who refused to countermand the order to send the last patrol, eleven of whose twelve members died futilely on the eve of peace. His past inhumanity is doubled by his current political career, but both these things provoke Diaz's anger. Chimay, who heads a political movement with two million members and has the ear of the Minister of Defense, does not hesitate to push the country to mobilization and the brink of war with an unnamed enemy that, given the 1936 remilitarization of the Rhineland, was unlikely at the time to be taken for any other than Hitler's Germany.

As if this adventuresome scenario were not already complicated enough, Diaz, prior to this episode of French war fever, has also moved to the spot where he was last wounded, near the Douaumont military cemetery where the other members of the last patrol are buried. Gance is clearly borrowing here from the sensibilities of the period. As Winter indicates, "it was natural that ex-soldiers should feel a special responsibility to their fallen comrades," and the "wartime pledge not to forget the tombs of the fallen, stated openly in French trench journals, was honoured in later years in front of village war memorials." 29 Diaz takes common practice much further: at his makeshift laboratory near Verdun, he pursues his "peace" research and begins to frequent the dead through a secret tunnel to the burial ground. He makes the frightful discovery that the dead are restless, and that, uncannily, they can be revived at his command. This unsettles him, so he returns south where his agitation causes the shrapnel to shift and he loses his wits entirely.

Edith then cares for him in St. Cloud, near Paris, where her soon-to-be son-inlaw, Chimay, pursues his political career. On the very day of nationwide mobilization, Diaz is shocked to his senses, takes a train to Verdun, and calls upon the war dead (his four million "friends") to rise from the cemeteries, in the guise of the ossuary of Douaumont, to prevent the impending war. They comply, but the populace burns Diaz on a pyre, since he refuses to order the dead back to their graves unless the civilians stop the war. In the words of the promotional brochure that Forrester-Parant distributed to theater owners, "The Estates General, convened in haste, declare worldwide peace, giving homage to the memory of Jean Diaz who succeeded, through his beliefs, in avoiding a new and horrifying catastrophe .. . Joy reappears everywhere. A new era of peace begins." 30 The ending of the film is more pointed, however. The radio announces that widespread panic has brought about the suspension of all military operations: "terror immobilizes Europe." Scenes of panicking civilians (including a close-up of a fleeing couple that looks suspiciously like the nephew seekers, Uncle and Madame Lebègue, in Tavernier's La vie et rien d'autre!), ${ }^{31}$ stopped trains, and idled factories are followed by a sequence of rapid shots that take the viewers through an empty Paris: the Bourse, the National Assembly, the Place de la Concorde, the gargoyles of Notre Dame-all are abandoned because of the return of the dead, provoked by Diaz's eschatological cry: "soldiers, sailors, aviators, my $12,000,000$ friends killed by the war . . . the living want to start war all over again!" The camera then moves to the assembly hall for the Universal Estates General, convened in haste. It is the opportunistic demagogue Chimay who 
abandons his usual speech on the need for a strong army and instead becomes the spokesperson for the assembly, announcing to rousing applause that "war is solemnly abolished between all states and immediate disarmament is unanimously decreed." The dead then return to their graves, namely Douaumont. (The commercial version of the film currently available in the U.S., reissued in 1991, concludes with the death of Diaz but without the convening of the Estates General. The effect of the conclusion, much changed, suggests that war is inevitable rather than preventable.)

As always with Gance, a complicated sentimental plot parallels the historical developments, in both silent and sound versions. King has noted the stark contrast in Gance's films, even the later masterpieces, between epic and melodramatic elements. ${ }^{32}$ Close-ups alternate with panoramic views of landscape. The spectator is strongly invited to identify with the protagonist Sisif of La roue (The Wheel) or Diaz of J'accuse, but he or she is also thrust into a broader perspective of "universal truths," of the "artist confronting destiny." 33 King sees this alternation of perspective, or "melo-epic," as Gance's version of modern myth and as more typical of the filmmaker's art than the superimpression that characterizes the return of the dead in the two versions of $J^{\prime}$ accuse. ${ }^{34}$ The sentimental triangle is the same in 1919 and 1938, with some changes in the modality of the configuration: Diaz loves Edith, wife of jealous François Laurin. In 1938, Edith's child by Laurin is Hélène and no longer Angèle; unlike Angèle, Hélène is not offspring from a rape by enemy soldiers; the insistence is no longer on Laurin, the physically abusive brute, though he does still have a temper, and Jean eventually seeks (unsuccessfully) another love, namely Helène, though his true love remains, throughout, Edith ${ }^{35}$ Gance's contemporaries (among them: René Clair, Léon Moussinac, and Louis Delluc) noted the implausible aspects of Gance's ideological "cinema of ideas" where technology, elite literary allusions, and charismatic politics abound. ${ }^{36}$ Such skepticism notwithstanding, the picture of the disharmony, separation, and dissatisfaction that the love triangle brings to Gance's films, including not just the two versions of J'accuse but films throughout his career like Mater dolorosa (1917), La roue (1922), and Un grand amour de Beethoven (1935), has a legendary, archetypal force that can be traced to the filmmaker's illegitimate birth and to a childhood divided between his working class mother and the distant aid of his well-to-do father who was a doctor. ${ }^{37}$

As Williams remarks, however, Gance believed in the power of this odd mixture to convey his message, which, in the case of Jean Diaz, appears as a messianic, utopian attempt to save society from its own conflicts. Far from playing to the public's taste for the grandiose and the passionate, Gance's overt politics, apocalyptic endings, and tragic loves are at the core of his artistic project: "Gance clearly took these stories seriously and thought they could tell great truths." 38 Part of the power of Gance's films comes from the feeling one gets, as in the silent and sound J'accuse, that the love triangle is at odds with the political message, or at least that love interests and politics obey different if obliquely related artistic impulses, a tension that Tavernier attempts to resolve in La vie et rien diautre. To use a French expression, Gance's films ont les qualités de leurs défauts, they draw strength from their very flaws: "A number of disparate 
elements are to be found in his films because he put them there deliberately, so that his work could become the site of their reconciliation," says Williams. ${ }^{39}$ In $J$ 'accuse, Gance's montage brings together widely varied, disparate images. From Gance's unexpected dissolves and fade-ins of the home front and battle, from his superimposed images of the dead upon the living, and from his jumpcuts from cemetery path to townspeople, the spectator must form a vast, unified image of war.

The melodramatic plot of the silent $J$ 'accuse has a different effect, however, than the later sound version. For the first half of the extant three-hour silent film, Jean Diaz is constantly at odds with François Laurin. Laurin knows that Diaz is his rival for Edith's affections, and when he surprises them during one of his hunting sprees, he shoots uncomfortably close to the couple, killing a bird right next to them, in one of Gance's trademark sequences in rapid montage. A face-toface confrontation between the two men follows. Later, after the outbreak of war, Diaz is discharged from the army for health reasons and he returns to Orneval. When Laurin returns on leave, Diaz pretends that Edith's offspring from the rape is his ward, confided to his care by a relative, but Laurin suspects Angèle is Edith's love child by Jean. Eventually, Edith and Jean recount the tale of the rape by German soldiers and restrain Laurin's murderous rage. Laurin returns to the front to seek vengeance, and with the same motive Diaz re-enrolls as an enlisted man under Laurin's command. He and the jealous husband reconcile. After Diaz's hospitalization for shellshock, he manages, though still dazed, to escape and wander back to Orneval, where he conjures the dead. By then, Laurin has perished in battle, yet Jean himself dies surrounded by the care and affections of Edith and Angele. The reconciliation of Laurin and Diaz in the second half of the silent film allows the spectators to concentrate on the paroxystic return of the dead that closes the story. ${ }^{40}$ The melodrama can give way to the film's ideological demand that society honor the sacrifice of the dead, via Jean's final, desperate comments on his own poem, Les pacifiques. Gance's nationalist pacifism assumes a central position in the end because of the way he construes, and finally dissipates, the tensions in the love triangle. ${ }^{11}$

In the sound version of 1938, Gance's construction of the melodrama shifts considerably and creates a more unambiguous platform for the filmmaker's pacifist message than we find in the silent version. The hostility between Laurin and Diaz is quickly defused: very early in the film Laurin dies in the field hospital, holding Diaz's hand; Diaz out of loyalty and respect for Laurin has promised not to pursue Edith any further. Laurin's former function, as rival in the silent film's narrative, is taken over by the man who more or less sent him to his grave, Chimay, former officer and now industrialist. Both in war and in peace, Chimay is Diaz's hierarchical superior and definitely represents social and political evil, absconding as he does with Diaz's formula for steel glass, in the historical or epic portion of the film. Melodramatically, Chimay is also Diaz's rival, and a victorious one at that, since Hèlène, Edith's daughter, marries him instead of Jean. By the end of the film, Jean dies, isolated from his true love Edith and from his surrogate love Hélène, but fighting the archenemy, Chimay, who incarnates war. Jean's war experience, his love rivalry, and his struggle for peace center on the 
same nemesis, Chimay. There has been a paradigm shift for Gance between the end of the war and the 1930s: the enemy is within, and he represents absolute evil.

While King is right to note that in the silent film, Jean's final vision of the return of the dead in a way memorializes his dead friend François and gives Jean a sense of loyal completion, ${ }^{42}$ we should go further and assert that in 1938 incompleteness holds sway over fraternity. This is appropriate, too, in that the silent version deals explicitly with remembrance and memorialization of the war dead, and only implicitly (by suggestion and irony) with the problem of preventing a future war. By contrast, Gance clearly attempts to position the 1938 film in a performative stance with respect to an impending world conflict. It tries to conjure up obstacles to renewed violence. The filmmaker's statements in promotional brochures that his distributor, Forrester-Parant, sent to theater owners ("à l'intention des exploitants") market the film as a pacifist work: "It cannot be true that the sacrifice of millions of human beings, whose cold bodies are not yet decomposed, has been in vain ... It cannot be true that we are helpless to prevent lighting the fire that consumed them;" 43 "I have tried to capture in sound and images a moment of this dizzying fall of today's men toward war," "[this film is] the compelling call of the Dead to those whose duty it is to impose the peace"; "So that day rises tomorrow on a calm and happy France, and not on a field of dead."45 To emphasize the internationalist aspect of the film's pacifism, the first page of a brochure, echoing the opening shots of the film, announces that the work appears under the aegis of the Byrd Foundation for World Peace and is sponsored by veterans' associations, including one affiliated with the League of Nations. ${ }^{46}$ The film's conclusion is ambiguous, however. Peace is achieved but at the price of Diaz's death, and Gance's work appears like a utopian gesture carried out by another of the filmmaker's prophetic and pathetic heroes, far ahead of the times, like Napoleon, destined for ruin after the last stand. ${ }^{47}$

The 1938 J'accuse is decidedly internationalist and pacifist by contrast with the silent version where the rape of Edith pitted Laurin and Diaz against Germany. In the concluding scene of the sound version, Jean Diaz shouts in French, English, and German for the dead to rise up in revolt against the threat of renewed warfare. One would be hard put to find any of the traces of Germanophobia that characterized portions of the silent J'accuse, at least on screen. A Forrester-Parant promotional brochure for the sound remake does contain a Germanophobic quotation from Colonel Picot: "After the armistice, President Clemenceau insisted that five soldiers with face wounds sit around the table where the German delegates would sign. He thereby marked his will to keep the signatories' eyes riveted on such a cruel testimony to the horrors of the war, horrors prolonged in the atrocious stigmata on the mutilated faces of our wounded. In the same spirit, I asked my friends, the Gueules Cassees, to participate in the film J'accuse."48 The colonel's quote ("our wounded") echoes the nationalist, anti-German theme of the silent $J$ 'accuse, but none of this rhetoric seems to have made it into Gance's sound version. Instead, the portrayal of Chimay hints at the inward gaze typical of the fratricidal, internecine guerre franco-française that raged from 1934 forward through the Liberation and the post-WWII Purge. ${ }^{49}$ 
Chimay's introduction is a modification of the original plot that has especially important ideological implications. Gance chose a French politician and industrialist to play the role of warmonger and bear the burden of war guilt. Chimay is reminiscent of right-wing protofascists like champagne magnate Pierre Taittinger whose paramilitary Jeunesses patriotes were involved in the volatile conflicts of the 1920s between French right and left, but even more so like the "respectable" alliance of business and extreme right demagoguery typified by Colonel de La Rocque, whose public image in the 1930s was decidedly coat-andtie, despite his fiery menacing rhetoric. (La Rocque and his supporters vacillated when militant groups of the extreme right rioted on the Place de la Concorde and attempted to enter by force the nearby National Assembly on 6 February 1934. Soon thereafter, he converted his protofascist group, the Croix de feu, into a parliamentary political party, once the Third Republic outlawed paramilitary pressure groups. $)^{50}$ The enemy of peace in the 1938 J'accuse is no longer the hereditary Prussian foe across the Rhine, but an opponent within, the industrialmilitary complex animated by the unscrupulous personal ambitions of Third Republic parliamentarians and demagogues, personified in Chimay. One legendary enemy has been replaced by a conspiratorial shadow figure that is just as mythical: the plutocrat who risks the nation to pursue personal profit, public visibility, and careerism. The gesture of blaming plutocrats and parliamentary chicanery for impending war is ambiguous and belongs as much to the superpatriot right as to the internationalist, pacifist left, but Gance was attacked in the early 1930s as an example of Jewish influence in French cinema by the likes of the right-wing monarchist newspaper Action française. ${ }^{51}$ The filmmaker, in a gesture that places him out of the frame of reference of the authoritarian right in 1930s France, collaborated with, and shared the internationalist ideals of, the League of Nations. ${ }^{52}$ This did not however keep Gance, a political nonconformist at best rather than an orthodox leftist, from corresponding about his film projects with Franco and Mussolini, and he became solidly Pétainist once Hitler occupied France. Gance's fascination with the providential man and with society's need for profound moral reform led him into an awkward association with movements seemingly so opposite: interwar pacifism and Pétain's national "renewal."s3

In large measure, Gance's vision from 1919 to 1922 accuses so that it may memorialize the war dead. The silent film aggrandizes the soldiers' sacrifice as much as it is indicts the brutality of the Germans or the injustice of war itself, whereas in 1938 the accusatory thrust of the images and plot has become primordially pacifist with marked internationalist sympathies. The gaze is no longer so exclusively directed backwards on German war crimes or on unsupportive civilians; instead it has been reoriented toward future threats of war which have become preoccupying because of domestic politics (the antiparliamentary riots of 1934, the instability characteristic of the late Third Republic) and dilemmas of foreign policy (Hitler's rise to power). This shift from memorializing to premonition may seem counterfactual given Gance's insistence on visual shots of the Douaumont monument to the dead of Verdun in the beginning and ending sequences of the $1938 \mathrm{film}$, but the monument itself was just the last major episode in France's national commemoration of the war dead. 
Only partially erected when it was officially inaugurated on 18-21 September 1927, it was not completed until August 1932. Even more significantly, the filmmaker started making the new version of J'accuse in June $1937,{ }^{54}$ and on 1213 July 1936, 20,000 veterans from France, Italy, and Germany held a procession at the ossuary of Douaumont, where they swore to protect and promote the peace. ${ }^{55}$ In his remake, Gance puts the great tower or ossuary at Douaumont to very effective use. It sends forth beacons into the surrounding night, as though animated and keeping watch against the onslaught of a new war. Diaz speaks directly to it, asking if he has understood correctly his mission and its moment, and the beacon flashes in acknowledgement: the dead leave under its vigil and return to haunt the living. Historian Antoine Prost's description of the July 1936 veterans' procession is worth reading to understand both Gance's sequences at Douaumont and the power that the monument had in the popular imagination: "the veterans went up on foot, at night, to the Douaumont cemetery, silently, no smoking allowed, while loudspeakers broadcast funeral music; then they each placed themselves behind a tomb, observed a minute of silence, and gave together the solemn oath." ${ }^{\text {"T }}$ The description in the official program of the ceremony is itself priceless for restoring the historical context of Gance's $1938 \mathrm{~J}$ 'accuse: "And Douaumont's high solitary lantern, each night pouring its light down on the tombs and on the bruised lands guarding their cadavers, exhorts men today and tomorrow to wisdom and peace." $"$ As Prost indicates, the commemoration was emotionally powerful but short on practical advice to avoid a further war.

\section{Interwar Pacifism and the 1938 Sound Remake of J'accuse}

Icart notes the mixed reception of the film from its Paris premier in January 1938 through projection in the provinces (spring through fall 1938, roughly the duration of the Anschluss and the Munich crisis): "But could one imagine, as Gance naïvely did, positive reactions [to the film] resulting in a heightened consciousness and in mass action? Even then, critics and the public would have to have followed along, which was not generally the case." 58 As King says though, and as Prost's portrait of veterans' movements shows, however outmoded Gance's grandiose utopian politics may appear today, they were "very actual...in the years 1918 to 1939." The filmmaker's "romanticism is specific to the inter-war years in France," and it is "both committed and essentially political in its effects." Icart's incredulous reaction to Gance's implicit call in 1938 for mass action to stop the coming war does not delve into interwar pacifism which resonates to many of the themes in the filmmaker's sound remake of $J$ 'accuse.

As historian Norman Ingram indicates, interwar pacifism, though important, was "a balkanized, splintered movement." 60 In the late 1930s, the extreme right even adopted an opportunistic version of pacifism, referred to by Ingram as the "pacifisme des munichois," in order to avoid war with Nazi Germany. ${ }^{61}$ Future collaborationist Marcel Déat, a graduate of the highly politicized Ecole Normale Superieure like Alain, asked his compatriots in a newspaper article in May 1939 if they wished to die for Danzig. French interwar pacifism had more profound leftist roots, however, as far back as 1887 and the foundation of the Association de la 
paix par le droit (Association for Peace Through the Law, or APD), which represented the "old-style juridical pacifism" that dominated French peace movements from 1918 through 1933, when a more radical approach surfaced: integral pacifism. The APD, politically close to the Radical Party, counted membership of 6,000 to 7,000 between 1929 and $1938 .^{62}$ In 1919 , and the immediate aftermath of World War I, APD luminary Theodore Ruyssen took a stand very similar to the pacifist nationalist stance of Gance's silent $J$ 'accuse: any relations established with German peace movements had to be pursued on the basis of German acknowledgment of its exclusive burden of war guilt, that is, article 231 of the Treaty of Versailles, unrevised. Future peace could not be assured by excusing prior aggression. ${ }^{63}$ Gance's ideology, at least during the filming of the first version of J'accuse, was thus in unison with a significant segment of French pacifist opinion. It is no coincidence that, as Icart points out, the film's title itself hails not primarily from Zola's famous work on the Dreyfus affair but from a pamphlet, J'accuse!, published in 1915 by Payot, in which Austria and Germany are implicitly condemned for the bloodshed. ${ }^{64}$ Icart, who notes that the scenario of the first, long version of the silent film was both antiGerman and "not very pacifist," attributes this to the timing of the film, which was made in the fourth year of the conflict, when the French public's anti-German emotions were at their most bitter, preventing Gance from expressing his deep sympathy for an absolute, unconditional pacifism. ${ }^{65}$ This does not mean that the filmmaker's pacifism was insincere, nor that his film was without serious impact in establishing durably the antiwar atmosphere that a historian like Eugen Weber sees as dominant in France of the 1930s, even outside left and centrist pacifist milieus. ${ }^{66}$

The years 1932-1933 witnessed a split between the more traditional pacifism of Ruyssen and the APD on the one hand, and the integral pacifists on the other, who questioned the validity even of wars of self-defense and believed, as a last resort, in unilateral disarmament. ${ }^{67}$ Ingram attributes the split between the APD and integral pacifists not just to the threat that Hitler's rise to power represented for peace, but to the growing evidence that the League of Nations could not mediate, through the law, international conflicts like the Sino-Japanese war or the Italian invasion of Ethiopia. As Franco-German tensions heightened with the remilitarization of the Rhineland in 1936 and German intervention in the Spanish Civil War, Ruyssen and the ADP concluded that defensive combat might be necessary to avoid political enslavement. ${ }^{68}$ For the legal-minded APD, "attachment to the cause of justice gradually assumed overriding importance over the question of peace" in international conflict, a tendency that the Munich crisis only accentuated. ${ }^{69}$ In contrast to the APD, the new generation of integral pacifists continued to reject all war, even against a foreign aggressor. Alain, as early as 1923 in the periodical where his essays appeared, Libres propos, had attacked the APD's notion of la paix par le droit (peace through justice, namely the negotiation of disarmament treaties and the recognition of higher instances of international law, specifically the League of Nations), since this maxim implied the use of force to elicit obedience to international tribunals. ${ }^{70}$ By 1932 , dissent within the ranks of Ruyssen's organization was rife. Members such as Félicien 
Challaye and Leon Emery initiated the internal debate that would lead to the formation of rival movements, most especially the Ligue internationale des combattants pour la paix (International League of Veterans for Peace, or LICP), the leading formation of integral pacifism, led by Victor Méric until his death in 1933, and then by René Gérin. ${ }^{71}$

Two other differences that came to the fore in the 1930s between the juridical pacifism of the APD and the extremism of integral pacifists help situate Gance especially well. First, integral pacifism had roots in the rejection of the official French version of the causes of WWI, namely that the Central Powers, especially Germany, bore sole responsibility for the outbreak of hostilities. ${ }^{72}$ This would seem to oppose integral pacifists to Gance, at least as far as the silent $J$ 'accuse is concerned, with its indictment of German violence against civilian populations as symbolized by Edith. In 1938, however, Gance does not recycle the issue of German war guilt in his sound remake, indeed he completely eliminates this theme and thus mutes a major issue of his silent masterpiece. The shift away from blaming the Germans does not make Gance an integral pacifist per se, but it does make his viewpoint much more neutral and compatible with integral theses. Second, another aspect of Gance's 1938 sound remake brings him very close indeed to integral pacifism, namely his film's anti-technological theme. The "increasing sense that another war could destroy civilization because of the progress made by science and technology" informed the political consciousness of many integral pacifists, ${ }^{73}$ and the sound version of $J^{\prime}$ accuse is very receptive to this idea. Gance changes his protagonist Jean Diaz from poet of Les pacifiques in 1919 to inventor in 1938 of verre d'acier, or steel glass armor plating. Gance clearly was mesmerized by the technological threat of modern warfare, and suits made of steel glass would allow the French to turn the other cheek when attacked, realizing the integral pacifist ideal of no war against other nations, not even a defensive one, the idea being to respond to aggression not with a counterattack but with technologically-assisted passive resistance, along the lines of a scientific Gandhi. Steel glass is the high tech equivalent of Alain's "say no" (but superarmor, of course, could also abet the offensive, a polyvalence that brings about Diaz's downfall and death). Ingram associates fear of technology with a nationwide campaign in 1930-1931, sponsored by the LICP: "This croisade de la paix, as it was called, brought home to hundreds of French towns and villages the pacifist message that the next war would be the last," because it would produce so much carnage. ${ }^{74}$ The campaign reached "tens, if not hundreds, of thousands" and showed that integral pacifists, like many in the 1930s, doubted the Third Republic's ability to maintain the good of the commonwealth, though the LICP did not affiliate with the Communist dominated Amsterdam-Pleyel movement supported by Henri Barbusse and Romain Rolland. ${ }^{75}$

The memories of the poison gas attacks of WWI gave special emphasis and urgency to this theme of technological overdevelopment, even up until the outbreak of WWII, as shown by the novelist Roger Martin du Gard's character Antoine Thibault whose death from the corrosive aftereffects of mustard gas 
concludes the writer's multivolume historical novel Les Thibault, the last volume of which appeared days before the Nazi invasion of France in May 1940. Antoine's death, in the Epilogue, was preceded by the death of his young brother, Jacques, in the volumes subtitled L'éte 1914 (Summer 1914), published in 1936, a short while before Gance began filming the sound version of $J$ 'accuse. Jacques, an integral pacifist before the fact, refused induction into the army when the general mobilization was decreed on 2 August 1914. He took refuge in Geneva in international socialist milieus opposed at all costs to the war and was summarily executed as a spy, after the airplane in which he was overflying the battle lines was shot down as he dropped leaflets urging troops on both sides to lay down their arms immediately. Eugen Weber argues that the death of this young idealist should not be taken as a sign of the futility of integral pacifism, but as a call to prevent at all costs the failure of peace. ${ }^{76}$ Martin du Gard went to great lengths, however, to keep his novel from becoming an ideologically unilateral roman $\dot{a}$ thèse, and though he refers to himself in his correspondence as a "gogo pacifiste" and was a self-avowed and longtime admirer of Alain's integral pacifist views, he also pointedly calls Jacques's overflight of the battle lines "that ridiculous raid," underlining the difficult if not impossible bind that integral pacifists confronted by the late 1930s. Gestures were becoming increasingly desperate, and at times futile. ${ }^{77}$ Diaz's gesture of recalling the dead of WWI is the reverse, mirror image of Jacques's flight since it directly fantasizes a successful stoppage of war, whereas Martin du Gard adopts the double edge of irony, which can cut either way, for or against his protagonist. Gance, unlike the novelist, was hardly loath to make the pacifist thesis of $J$ 'accuse obvious and unmistakable.

Like Jean Diaz's appeal to the war dead, or like Jacques Thibault's attempt to incite German and French soldiers to throw down their arms, the integral pacifists of the LICP and other similar factions believed that only popular, mass resistance could prevent another war. Like Thibault and Diaz, too, integral pacifism eventually failed to rouse the public enough to stop war with popular demonstrations. Ingram asserts that LICP membership, though still important up to the start of WWII, experienced a "leveling off from 1934 to 1936" followed by a "downward spiral," so its apogee corresponds to the period in which Gance conceived and filmed the remake of J'accuse. An appeal made in LICP leader Méric's own newspaper resembles Jean Diaz's desperate and relentless quest for peace in 1938 (or perhaps it is Méric who unconsciously recalls the resurrection of the dead in Gance's earlier silent film, which had reruns in Paris theaters at least as late as 1928): "If some lunatic were to take no account of the popular desire for peace, and were to let loose the massacre, it would be up to the people to resist the fact of war by all possible means: general strike, individual or collective action, passive or violent."79 Gance adds his own typical messianic twist: the local populace in his 1938 film is not ready for Diaz's message and crucifies him instead, though his martyrdom then spurs politicians in the person of Chimay and the Estates General to declare worldwide peace, in a grandiose but utopian gesture. Pacifists like Méric, according to Norman, "did not attempt 
to provide positive answers to the problems of peace," other than vague calls for a nationwide workers' strike to prevent arms production, or pleas for unspecified individual action. The LICP "contented itself with increasingly sterile anathemas hurled at French political society. [Méric] balanced on the fine line between total despair-announcing that war was imminent and inevitable-and calling on the French to resist its fatality." The LICP's most illustrious member, Rolland, resigned in 1933 because of the organization's impractical agenda. ${ }^{80}$ The notion of an Estates General against future war was hardly Gance's impractical brainchild, however. The motif was already very popular in veterans' organizations, witness the highly publicized "Etats Généraux de la France meurtrie" (Estates General of Wounded France), officially opened at Versailles by Poincare, where 635 delegates representing 2.5 million veterans of WWI met from 11-13 November $1927{ }^{81}$ The delegates concluded by urging officially that the government guarantee peace through international respect of treaties (an idea in fact closer to APD policy than to the LICP, but Gance, notoriously eclectic, was never shy to amalgamate influences if it served his overall political goals).

There is a final, telling resemblance between integral pacifism and Gance's 1938, new-style antiwar sentiment: both share the notion that the enemy is not so much Hitler, whom German pacifists themselves must oppose and defeat from within, but the threat of a French fascism, hence according to Ingram the integral pacifist proviso that violence is occasionally justifiable in civil wars. ${ }^{82}$ Chimay incarnates this sort of internal nemesis, which integral pacifists considered a greater threat than the increasingly unstable international environment: "The idea was . . prevalent that Nazism and Hitler were not really much different from the capitalist ruling classes in the democracies," an impression furthered by Hitler's successful press campaign in France, including a tame 1934 interview with the daily Le matin. ${ }^{83}$ Chimay represents this Franco-French enemy that the integral pacifists saw variously in "the capitalist governing class, the military caste, or simply the politicians of the Third Republic." ${ }^{84}$ Not even the internationalist Popular Front garnered the LICP's support, though the pacifists drew some confidence from the efficacy of the nationwide strikes that followed Blum's electoral victory in spring 1936, since this augured well for the LICP's strategy of a general strike to prevent war. ${ }^{85}$ In 1938 (but after the premier of the sound version of J'accuse), the LICP's leader, Rene Gerin, along with Alain, hailed the resolution of the Munich crisis as the beginning of a welcome "peace

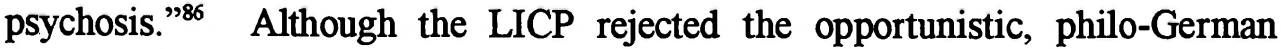
pacifism that concurrently showed its face on the French extreme right, Gerin, like Alain, maintained the unconditional call for peace until the eve of WWII. ${ }^{87}$ This, however, takes us far beyond the circumstances informing Gance's 1938 J'accuse.

While Gance's sound remake of J'accuse has definite points of contact with the LICP's version of integral pacifism, the contrast between the filmmaker and the highly individualistic philosopher Alain, arguably the best known single representative of French interwar integral pacifism, casts a somewhat different, 
more critical light on Gance's pacifism. J'accuse, in its various versions, is a unique set of antiwar documents, and during the interwar era the silent version, as much as Alain's Mars ou La guerre jugee, was an icon of the French reaction against WWI. Alain espouses the main tenets of integral pacifism: the need to renegotiate WWI treaties; the urgency of disarmament; the idea that fascism should be treated, and could be defeated, as an internal political affair, and the opposition to any and all foreign wars. ${ }^{88}$ Gance, with his quasi-mystical view of the relationship of individuals like Jean Diaz to the polity, is far from Alain's rationalism which locates (and rejects) war's appeal in the esthetic pleasures it gives officers, hawks, and even the run-of-the-mill poilu gripped by the "rythme contagieux" of military discipline, ceremony, and esprit de corps (Mars, 260). By contrast, Gance's films appeal explicitly to enthusiasm and betray an exaggerated romanticism: "[Gance's] system of representations is one which, by occulting contradictions, has as its specific function to construct a unity for the spectator, a unity which should be poetic and popular, appealing not to rationality but to universal emotions . . to the hearts of the masses." ${ }^{\text {"g }}$ Diaz's final struggle against the threat of war, and his fantasy of appealing to the dead of WWI, exemplify and sustain King's critique.

Despite this fundamental difference between Gance and Alain, there are also points of contact. Alain's 1936 re-edition of Mars ou La guerre jugée was not a straight reprint of the 1921 original (which had been motivated primarily by Alain's recent and lengthy combat experience in WWI). Twenty new brief texts, written between May 1921 and December 1934, were interpolated among the original propos. (The supplemental essays are assembled in the current Folio edition of Mars under the separate title of Vingt propos sur la guerre). Although Alain published many other antiwar essays in the review Libres propos and even a Suite de Mars in 1938, the augmented 1936 edition of Mars ou La guerre jugee provides a representative view of his pacifism, and one which was current at the time Gance was filming the sound version of J'accuse, itself hardly a sonorized replica of the original film. Like Gance, Alain is cynical about unscrupulous politicians (shades of Chimay) who push domestic political opinion toward war when it suits their personal ambitions. In this, both Alain and Gance are faithful to the integral pacifist tenet that wars must be prevented by bringing pressure to bear on internal domestic politics. The challenge of warmongering and fascism must be met and defeated at home: "as many times as the politicos announce war, just so many times will the people agree to wage it ... That is why war and peace depend primarily on domestic politics" (Mars ou La guerre jugée, 28990). Alain often was close to the views of the center-left Radical Party but remained generally aloof from party politics. In his biographer's words, he was a "a resolute and unrepentant maverick" in politics, ${ }^{90}$ as much a nonconformist as Gance. Under the pressure of events, and primarily in order to combat the French extreme right that had shown such force during the riots of 6 February 1934, Alain co-founded the Comité de vigilance des intellectuels antifascistes (Vigilance Committee of Intellectuals against Fascism, or CVIA).$^{91} \mathrm{He}$ espoused a political ethic that revolved around the contestation of power and authority: 
"The supreme rule of thought is to be wary of thinking on the Prince's side," he says in one of his essays. ${ }^{92}$ The "forces" in the following quote from Mars ou la guerre jugee are the powers of the government, and "they" are the people who despair of stopping further wars: "if, as I have done, they took the oath never to be weak in the confrontation with the forces that be, the dead would forgive" (171). Alain's phrase coincidentally foreshadows Jean Diaz's final confrontation with French society, in the grip of war fever in the closing moments of the 1938 J'accuse.

Given Alain's antiauthoritarian tendencies, it is not surprising that he devotes much thought to the military hierarchy and soldierly obedience: "It remains true that a leader's energy is a rare thing. . . But a harvest of cadavers is something worth taking into account, too" (Mars, 221) ${ }^{93}$ Keeping in mind, no doubt, the mutiny that Petain stifled at Verdun, Alain asserts that blind obedience is unnatural: "Revolt is profound, and everpresent, I would even say part of the institution in any and every army," but most often the soldier tames his instinct and avoids contesting the officer's exorbitant powers, since most likely this would result in summary execution (Mars, 100). ${ }^{94}$ Alain does not adulate leadership, only individual conscience: "I am sovereign. . . . The sovereign's moment is when he pronounces judgment, not when he passively accepts," and Alain equates personal sovereignty with the rejection of war, since war annuls all freedom of action or thought, in self or in others (Mars, 229). Issues of command and obedience do not figure prominently in the silent $J^{\prime}$ accuse. Jean serves first as an officer, and friction occurs between him and enlisted man Laurin solely because of their rivalry for Edith's love. After Diaz's discharge for fragile health, he eventually re-enlists as a simple soldier to serve under Sergeant Laurin's command in order to avenge against the Germans the rape of Edith. Again, the issue of military obedience is subservient to other interests. Quite another matter is the 1938 sound version of J'accuse, where the morality of the military leadership immediately evokes Alain's refractory attitude toward officers and their cult of obedience: Chimay is responsible for sending out the archetypal last patrol which will be massacred. Diaz, a battlefield saint, volunteers to take the place of a family man, and in so doing effectively protests against the spirit behind the order. Miraculously, Diaz survives, and it is his volunteering (an implicit rejection of the inhumane military hierarchy) that solidifies his pacifist convictions after the war (convictions that were already visible, however, in the opening scenes of the movie, when he took great care to bury a dead dove on the battlefield, despite the bellicose nickname his fellow soldiers had given him, "nettoyeur des tranchées," the Attila of the trenches). At the end of the film, Diaz will also accomplish a second, broader act of symbolical, sublimated disobedience, namely stop mobilization for the next war by calling the dead to mutiny against the government and its profiteering, warmongering lackey, Chimay. The best time for disobedience is in peacetime, when draconian measures are not the rule, and when public powers feel the pressure of the masses, as Alain says: "powers, left to themselves, will always pursue a policy of armed peace, that is, a war policy. But they have said that 
outright. . . . If the body of citizens does not continually apply firm, pointed pressure against any preparation for war and even against the idea of war, war will organize itself on its own" (Mars, 109). Diaz's revolt at the end of the film, on the eve of a new war, is just such a peacetime, antiwar pressure tactic, although in Gance the rebellion assumes a poetic, or hyper-romanticized, form.

Alain's language-war will organize itself-hides, however, a major difference with respect to Gance: for the essayist, war results from unbridled human passions, like the ones that a classical moralist such as Pascal used to describe humanity - ambition, desire to command and not obey, the enthusiasm that ceremony and circumstance instill in the heart, the spirit of the game and competition, or more simply, anger fueling further anger: "Make war on your passions [that are] so exciting during the spectacle or the parade, but above all in the midst of victory. To all these intoxications, say no" (Mars, 257).95 Gance, on the other hand, seems to assign war's causes to the juncture of self-interest (since Chimay's political ambitions lead to his misappropriation of the formula for steel glass) and of economic interest (because Chimay is, after all, president of the glassworks that will profit by the government's adoption of steel glass as armor). Alain, by contrast, is explicit in his rejection of profiteering and economic interest as the true causes of war: "When I hear people say that selfinterest is the main cause of war, or ... that economics hurls people against each other, I do recognize this as a widespread idea. ... But once I examine it, I judge it to be a feeble one and truthless" (Mars, 298). Although Alain's analysis is oriented toward the causes of Germany's entry into WWI, and toward questions of national economic survival rather than war profiteering by greedy industrialists, the principle is clear and applicable to the case of a Chimay whose political and economic actions are at best, if we follow Alain, an incidental factor in the outbreak of any war: "Warriors are neither thin nor starving, [they are] well-fed and strong-blooded, to the contrary; and flaunting their force, and drunk on their own force ... [Their] hands [are] ready to strike, not to pillage. [They seek] victory, not profit" (Mars, 300). Passions are the cause of war, not sales of steel glass and armaments: "Hurt self and others, without hope, without covetousness or calculation. Completely under the body's spell" (301). To prevent reason from being the captive of the "epic" (66), the pacifist must emphasize, according to Alain, the role that individual choice or will-"man, solitary and free by choice" (229)-plays in the public's acquiescence to war fever, whether encouraged or not by the rich and influential: "A millionaire would make me laugh if he wanted to rule me; I can always choose bread and water, and freedom" (Mars, 198). ${ }^{96}$

In J'accuse, Gance's depiction of war does not deny the role of passions: in the silent version, Diaz re-enlists out of a burning desire for vengeance. The filmmaker, though, also depicts his protagonist as the most passionate of crusaders against war. Diaz's reiterated interjections of "I accuse!" emotionally punctuate the silent film's patriotic beginning, the death of Diaz's mother, the contemptible behavior of the civilians, and the approach of his addled, lamentable death. "I accuse!" is hurled three times during the 1938 film, 
denouncing the nationalistic political demagoguery of Chimay, signaling the onset of Diaz's temporary amnesia when remaining shrapnel fragments cause his emotional breakdown, and, finally, accentuating Diaz's call for the dead of Verdun to rise to prevent the outbreak of yet another war, a war brought about this time by Chimay's public appeal (reminiscent of La Rocque's speeches) for a strong national defense and by his self-serving exploitation of steel glass. Passions are not a negative element in the filmmaker's lexicon, unlike the pojorative connotations they acquire in Alain's morality. All of Gance's talent is tied to what King refers to as his romanticism, that is, his passionate pleadings that post-WWI France remember its dead appropriately, and later, in the sound version, his use of Diaz's passion (in both senses of the term) as a means of preventing a second world war worse than the first. Gance depicts quasievangelical, messianic passions as the best means to combat war, while Alain austerely repeats that passions must be vanquished in order to end wars.

Nothing could be farther from Alain's rationalistic ideal than Gance's sacrificial, Christlike heroes whose saving grace comes not from any attempt to enlighten the masses with reason and realism, but to illuminate them on the mystical way to peace. In 1938, Diaz wakes from his amnesia in a moment of revelation, when a telephone operator tells him that national mobilization is underway for the next war. His road to Damascus is mystical, not rational, as his wide-eyed prophet's gaze suggests. Like the prototypical romantic hero, too, he is doomed to incomprehension and suffering. It is no coincidence that a grandiose project pursued doggedly by Gance from 1929, the year of the first sound films, was a series entitled Les grands inities which would have traced the interconnections of the great prophets of world religion including Buddha, Moses, Christ, Mohammed, Khrishna, and Confucius. ${ }^{97}$ The demands for remembrance that the Diaz of the silent $J$ 'accuse made are moderate when compared with his 1938 avatar's grandiose pacifist activism. The sound version of J'accuse exacerbates Gance's antirational tendencies, and this clearly differentiates the filmmaker from Alain. Whereas Gance's Diaz, especially in 1938 , contests the public powers that unleash war, he does so with means that differ considerably from Alain's, even if these two ideologues hold the common goal of preventing war. Each says no differently, the one by breaking war down to its causes in the one hundred thirteen propositions of the 1936 edition of Mars ou La guerre jugée, the other by staging remembrance emotionally through the return of the dead. Each counts his dead in a different manner as well, Alain in obstinate silence against military pomp and ceremony, Gance ostentatiously with panoramas of killing fields and superimpressions of the war wounded. Along with Martin du Gard's pacifist character Jacques from Les Thibault, and the LICP's call for a general strike to stop future wars, Gance and Alain both nevertheless show the intellectual currency that radical gestures had in 1930s French pacifism. Jean Diaz is hardly alone, even if his path is idiosyncratic.

\section{Gance and/or Tavernier: Comparison and Conclusion}

Alain, because of his rationalistic bent, resembles Diaz less than he does Major Dellaplane in Tavernier's retrospective glance on the war and on the 
government's indifference to the soldiers it sacrifices. In La vie et rien d'autre, a critique of militarism, parallel to the love story that eventually moves into the foreground, emerges from the satire of the government's insistence on interring an unknown but Franco-French soldier under the Arch of Triumph in Paris (and not an American soldier, or a German one, or a black soldier from the French colonial troops). ${ }^{98}$ Jean Cosmos indicates that, according to a recent edition of the almanac Quid, 252,900 French dead from WWI still remain unaccounted for. ${ }^{99}$ In Tavernier's film, at the official ceremony in the citadel of Verdun in November 1920, Minister Maginot watches a combatant, Corporal Thain, pick the unknown soldier from among eight caskets delivered from the different battle zones (less one zone which could not locate a suitable corpse). During the ceremony, there is one last confrontation between Dellaplane, who arrives late for the ceremony, and General Villerieux who is angry at the disdainful way his subordinate treats a ceremony of such national importance. Dellaplane responds in a whisper but bitingly, du tac au tac, and one can only think of Alain's advice to soldiers or citizens, quoted at the beginning of this study, that if they cannot absent themselves from patriotic commemorations, they should nevertheless count the dead, instead of acquiescing silently to the exploitation of the hecatomb (Mars, 257). Just as Alain ironically declares that the warmonger's most effective stratagem is to make the public believe that war is inevitable and that nothing can stop its fated appearance, so Dellaplane, during the ceremony, implies in a loud whisper to Villerieux that the government has a vested interest in channeling the public's remembrance away from the loss of individuals, each with a distinct etat civil, toward a single, vague, unnamable soldier, a symbol of national unity that allows the public to disconnect from the particulars of a war that killed over a million French soldiers and made more than two-hundred-fiftythousand unidentifiable. ${ }^{100}$

Gance's close-ups on the facial deformities of the Gueules Cassees at the end of the $1938 J$ 'accuse address, in their own way, what Dellaplane characterizes as the "scandal" of public forgetfulness, but the major's skepticism is still closer to Alain's point of view, in that it is aimed at the powers that be, war ministry, commanding generals, and the polity that wishes to ennoble through ceremony a human disaster so vast that epic exaggeration convinces us less of its immensity than do simple cold numbers. Tavernier and Cosmos emphasize this in the scene that pits Dellaplane against the absent, unseen Senator de Courtil, Irène's fatherin-law, who demands by letter that the search to ascertain his son's fate be given priority, eliciting the major's response to Irène, when he first meets her, that she will benefit from one three-hundred-and fifty-thousandth of his attention. Gance's return of the dead in his silent film is a more dramatic, apocalyptic version of Dellaplane's war statistics, since a last judgment is also necessarily an affair of numbers, both a roll call and an accounting. The major's imaginary, parodic parade of the war dead, on the other hand, would have taken a quasiBiblical eleven days and eleven nights, as opposed to the real victory parade's three hours, which shows that Tavernier's move toward litotes and attenuation is just a different, more realistic path toward excess. Tavernier's numerical version 
of the war dead's march would be unfeasibly long to act out and film without falsifying techniques of ellipsis and condensation (such as Gance's split screen parallel of the allied victory parade and the homeward march of the dead) that would weaken the consistency of Dellaplane's character, with his tenacious attention to detail and his maniacal accuracy.

Tavernier, on the other hand, is not averse to splitting the spectator's focus, and he does so in several discreet ways. More subtly than Dellaplane counts, the filmmaker conjugates two plots in La vie et rien d'autre: the search for the unknown soldier and the birth of love between Irène de Courtil and Dellaplane. Since Irène's husband is one of the unidentified war dead, the transition between the two plots occurs frequently and often imperceptibly, the theme of disappearance merging quietly into the realization that the official in charge has fallen in love with the person on whose behalf the inquest is being pursued. Statistics and love compete for screen presence until the very last words and image, and this constant double focus subtly distinguishes La vie et rien d'autre from $J$ 'accuse. Gance maintains the tension between pacifism and love interest only to evacuate it before the last crucial moments. In the silent $J$ 'accuse, once Laurin has been moved out of the picture, the camera is focused on the defeat of Diaz's ideals as conveyed in his poem Les pacifiques, ideals which even the return of the dead is not powerful enough to salvage. Soon after, Jean dies in despair, with the sunlight through a window designing a cross for his sacrifice, another example, as Winter indicates, of Gance's reliance on traditional religious images of suffering, side by side with sequences where his film technique innovates. ${ }^{101}$ The silent version of the film thus displaces love with pacifism. Similarly in the 1938 sound version, but in a much starker and direct way, Gance places the love story in ellipsis, or disables it by making both Edith and her daughter Hélène unavailable as viable love objects for Diaz. Diaz's last moments are focused entirely on the epic struggle to prevent the impending war through the appeal to the dead. Jean's last action conveys an ideological message: the unconditional call for peace against the nationalistic, capitalistic forces that Chimay incarnates.

Tavernier, however, seems on the verge of doing exactly the opposite in the penultimate scene of $L a$ vie et rien d'autre, that is, displacing pacifism with the love story. The spectator sees alternating scenes of southern France (where Dellaplane now lives) and New York City (where Irene temporarily resides, prior to an anticipated move to Wisconsin). Dellaplane has resigned from the army to private life in the country and, previously too timid and hesitant, he now offers his love to Irene. Just as the love interest, or melodrama, is about to displace Dellaplane's obsession with the war dead, however, he attaches a "postscriptum" to his love letter: his vision of the eleven-day, eleven-night parade of the war victims on the Champs-Elysées. Vision is a misnomer here, since the spectators only hear Dellaplane's voice recreated in the mind of Irene: she has already received the letter and silently reads its calculation of a virtual event. This is perhaps Tavernier's contestatory variant of a split screen, if we think back to the conclusion of Gance's silent $J$ 'accuse, but here image track and 
soundtrack are at a bias to each other, rather than two images being at variance on the same screen. Alternating shots, as opposed to split ones, show the exmajor and Irene and thus suggest the lag between the writing of the letter and the wait for a response. Dellaplane's letter concludes with two laconic remarks that prevent displacement of antiwar sentiment by love, or love by antiwar sentiment. His statistically painstaking rendition of the imaginary march of the war dead shares vocal space with his new sense of amatory commitment to, and yearning for, Irène: "Pardonnez-moi cette précision accablante. A vous, ma vie" ("Pardon my harsh precision. To you, my life"). He may never mention his statistics again, and he and Irène may or may not reunite, but in the only version we have of Tavernier's La vie et rien d'autre, it may be better to say that the tension between love and war remains suspended, given the surprising return of the war dead in the midst of a scene that is organized visually, even bucolically, around sequences of beautiful landscape and cityscape. The elegy for the dead is there in voice-over only, while shots of the civilian return to peacetime activities dominate the image track. Filmically, elegy and love letter, war and peace, are there simultaneously, unlike in Gance where the love interest is unseen at the end of the silent version (though the spectators know that Edith and Angele are not far away) and is entirely foreclosed in the sound version. The last sequence of Tavernier's film confirms the impossibility of repressing the catastrophe even though the participants will cope and move beyond. In 1989, seventy years after the Treaty of Versailles, WWI continued to be the irrepressible symbol of a war that was not the last. Tavernier recreated the emotional effect of a split screen, without ever using one.

As Dellaplane's voiced letter comes to an end, bringing La vie et rien d'autre to its conclusion too, we see the white vine stakes of his hillside estate: so many wooden crosses, a discreet allusion, perhaps, to the soldiers at parade arms, who fade to cemetery crosses in the opening of Raymond Bernard's 1932 film, Les croix de bois, which also has a concluding sequence where the dead, in a superimpression less grandiose than Gance's but carrying white and black crosses, pass by the dying protagonist Gilbert. Tavernier takes his image further than Bernard and distances his characters from the war itself when he refuses to film crosses, instead using vineyard stakes to pastiche them. ${ }^{102}$ The image track reflects the fading of Dellaplane's ties to the war, though the war remains as persistent trace. We should not forget, on a similar note, that in 1919 Gance planned a sequel to J'accuse, which he tentatively entitled Les cicatrices (Healing Wounds), which was never made because of Gance's legendary inability to manage the financial and practical sides of his moviemaking. His remarks on the thrust of Les cicatrices remain, however, and they are not as far as one might expect from the spirit of Dellaplane: "As for the future, it is better to plant a tree in the killing fields than an army banner over the cadavers. "J'ACCUSE" is intended as a preface to "LES CICATRICES" which will try, once justice has been done, to give a little solace to men by teaching them to smile. . . One always wakes from nightmares! Today, we tried to mutter the horrid dream, just as tomorrow we will try to sing the dawn of awakening and healed wounds." 103 
Jean Diaz had a gaze that could not sever ties to the recent past, since the outbreak of yet another war in the 1930s threatened to be more catastrophic. His only hope for recovery was that, thanks to the imposing return of the dead, the bellicose political configuration necessitating Gance's pacifism would not actually realize its potential for war. The filmmaker's successive versions of his great film on WWI, like the two versions of Alain's Mars ou La guerre jugée and numerous related propos, exhibit a preoccupation with peace that events did not resolve. Tavernier, on the other hand, reminds us that the memory of the twentieth century and its mass violence is inextricably bound not just to WWII but to the hecatomb with which our modernity, and its descent into the maëlstrom, disastrously began. ${ }^{104}$

\section{NOTES}

1. Alain, Mars ou La guerre jugée (Paris: Gallimard, 1995). References are to this Folio edition, hereafter cited in the text as Mars.

2. My notes and quotations for the silent J'accuse are based on the reduced, single-episode version available in the archives of the Cinematheque française, Fort de St. Cyr, France. Gance received a medical exemption at war's start. He served a few months as auxiliary in 1917 in the film section of the French Army. See Roger Icart, Abel Gance ou Le Promethee foudroye (Lausanne: L'Age d'Homme, 1983), 53, 103.

3. Bertrand Tavernier, La vie et rien d'autre, Orion Productions, 1989. According to Niall Ferguson, The Pity of War (London: Basic Books, 1999), 436-7, war dead on both sides exceeded $9,000,000$ out of more than $65,000,000$ soldiers. 15,000,000 were wounded. Eugen Weber, The Hollow Years. France in the 1930s (New York: W.W. Norton, 1994), 11, gives the figure of 1,400,000 French war dead, and 1,000, 000 "permanent invalids."

4. Dellaplane's calculations have at least one predecessor, Sir Fabian Ware of the Imperial War Graves Commission, who calculated the march of the British dead past the Whitehall Cenotaph at three-and-one-half days (Ferguson, 436).

5. On the different versions of the silent J'accuse, see Alan Williams, Republic of Images: $A$ History of French Filmmaking (Cambridge: Harvard UP, 1992), 87-8; Norman King, Abel Gance: $A$ Politics of Spectacle (London: British Film Institute, 1984), 237-8; and Richard Abel, French Cinema: The First Wave, 1915-1929 (Princeton: Princeton UP, 1984), 295-6. According to King, $J$ 'accuse was released in four episodes on 25 April 1919, then was reduced to three episodes, and in 1922 edited by Gance to three hours. See also Icart, 106. On spectators, see Jay Winter, Sites of Memory, Sites of Mourning: The Great War in European Culture and History (Cambridge: Cambridge UP, 1995), 138. Winter relies on the return of the dead in Gance's $1919 \mathrm{~J}$ 'accuse to symbolize the memory of WWI (especially 15-28, 133-8). He briefly mentions the $1938 \mathrm{~J}$ 'accuse and Tavernier's La vie et rien d'autre (27, 140-1). See also his "The Great War and the Persistence of Tradition: Languages of Grief, Bereavement, and Mourning," War, Violence and the Modern Condition, ed. B. Huppauf(Berlin: de Gruyter, 1997), 34-45.

6. Steven P. Kramer, Abel Gance (Boston: Twayne, 1978), 191; Abel, 297.

7. Winter, 69, 73.

8. Winter, 66-67, 204-207.

9. Winter, 73-6.

10. "Jean Cosmos scenariste ...," L'avant-scene CINEMA, no. 388 (Jan. 1990): 8.

11. "Jean Cosmos scenariste," 8.

12. Rondel Collection, Bibliothèque de l'Arsenal, Paris, France, $4^{\circ} \mathrm{Rk} .5395$.

13. On the Gueules Cassees and their federation, also known as the Union des blesses de la face, see Antoine Prost, Les anciens combattants et la societe française, (Paris: Presses de la Fondation Nationales des Sciences Politiques, 1977), 1: 88, 2: 49-50. Similar special-interest federations of 
veterans typically had 1,000-2,000 members but lobbied parliament actively. See also Winter, 45-6.

14. War wounded also participated in Gance's 1919 resurrection of the dead (Winter, 21). The war wounded are not framed as explicitly as in 1938, however, where Picot's troops (and troupe) are credited in the opening génerique and where they dominate the screen during the last moments of the conclusion, just before Diaz's death. Giant publicity banners of the Gueules Cassees were hung in Paris for the 1938 opening, but were taken down by ministerial order.

15. For Winter, the return of the dead in the silent film "transformed melodrama into myth" (18).

16. Williams, 86.

17. Rondel Collection, Bibliothéque de l'Arsenal, Paris, France, $4^{\circ}$ Rk. 5395. Icart quotes a similar if not identical statement from Gance himself (110).

18. Icart, 118-124, reproduces the portions of the scenario containing the trial.

19. Icart, 105, quoting Gance in August 1918. In addition, in his article "Pourquoi j'ai fait "J'ACCUSE"," in the trade periodical Hebdo-Film in 1922, Gance stated notably, concerning the three-episode version that was commercialized by Pathe Freres in March 1919, that "J'ai tenu, avant toute chose, à produire une oeuvre susceptible d'être accueillie avec la mème frayeur dans tous les pays du monde entier. Je me suis attachè à rester rigoureusement en dehors de toute profession de foi politique: ce genre de préoccupation est parmi les plus éloignées de ma pensée, et, d'autre part, il eut eté particulièrement dangereux de faire allusion à un point de vue politique quelconque puisque je visais a établir un film avant tout international, une repulsion definitive pour le fleau" (Rondel Collection, Bibliothèque de l'Arsenal, Paris, France, $4^{\circ} \mathrm{Rk}$. 5395). Other remarks in the same brochure, however, adopt the language of article 231 of the Treaty of Versailles, indicating that Gance intended to blame the war on the Germans: "D'une indignation lente, forte, implacable, naquit ce cri rouge: $J$ 'accuse, pour fixer indelébilement l'horreur de la guerre devant les yeux des assassins et des victimes et dresser le plus sincère réquisitoire possible devant le tribunal de l'avenir." We find again Gance's pacifist nationalism.

20. Willaims, $110-111$.

21. King, 158.

22. Abel, 302. King finds the same pattern in Gance's silent Napoléon vu par Abel Gance.

23. See Eugene-Emmanuel Lemercier, Lettres d'un soldat (août 1914-avril 1915), ed. André Chevrillon, 3rd ed. (Paris: Chapelot, 1916), 102-03. The original reads "Le temps est doux et la nature indiffërente. Les morts ne gêneront pas le printemps." The contrast between spring weather and the carnage of the war is a constant motif in this selection of letters written by a soldier (a painter in civilian life) reported missing in action on 6 April 1916.

24. On Gance's filming of documentary sequences at the front, and use of troops at rest behind the lines, see Icart, 105. Icart, 112, also rehearses the nationalistic elements in the silent version.

25. Winter, 46 , notes that the International Labor Organization estimated war invalids of all nationalities at more than $10,000,000$.

26. See Winter's analysis of the sequences where Diaz shouts "J'accuse!" (Winter, 136). The first two blame the Germans, the third indicts the home front, the fourth accuses nature.

27. Ferguson, 340 , notes that such patrols were commonplace, even during lulls in the offensive.

28. On the shift from poet to resolute man of science, see King 137.

29. Winter, 97.

30. Rondel Collection, Bibliothèque de 1'Arsenal, Paris, France, $4^{\circ}$ Rk. 5395, BRO 00189.

31. See, in addition to the film itself, "La vie et rien d'autre. Decoupage plan a plan apres montage," L'avant-scene CINEMA, no. 388, 81-3.

32. See also Rodney Farnsworth, "The Stylistic and Intellectual Unity of Abel Gance's $J$ 'accuse (1938)," Purdue University Seventh Annual Conference on Film, March 24-25, 1983 (West Lafayette, Indiana: Purdue University, 1984), 229-33.

33. King, 126-9

34. King, 128, 130. King also argues that in the shortened version of the silent $J$ 'accuse "the melodramatic . . . survives, at the expense of the epic" (130), but I feel that the return of the dead and the war scenes still introduce epic elements. Since Vergil, epic is not just grandiose representation, but treatment of events of national importance (if not more simply war, as in the Iliad). 
35. Abel Gance, J'accuse, The Film Preserve Limited, 1991. I also consulted the complete version available at the Bibliotheque nationale, Paris, France: Gance, J'accuse, Neuilly-sur-Seine: Film Office, 1937 (the date filming was finished). The Film Office copy at the B.N. was reissued after WWII, as a number of addenda prior to and after the film per se make clear. The addenda argue that France did everything to avoid war in 1939, that the French at the time "championed with steadfast conviction a universal peace based on justice against violence and against tyranny," and that after the war the French remain in the "avant-garde" of the "peace offensive."

36. Williams, 88-9, 92; Sadoul, 382-4; Winter, 137-8.

37. Williams, 84-85.

38. Williams, 85.

39. Williams, 90.

40. King notes how Gance modifies the topos of the warring brothers in his films, and how he puts rivals on the same side so as to avoid a stark opposition of virtue and vice (132).

41. Winter contrasts Gance's parochialism with Barbusse. See Winter, 178-6.

42. King, 135.

43. Rondel Collection, Bibliothèque de l'Arsenal, Paris, France, $4^{\circ}$ Rk. 5395, BRO 00006, 1.

44. Rondel Collection, Bibliotheque de l'Arsenal, Paris, France, $4^{\circ}$ Rk. 5395, BRO 00006, 7. Icart, 277, 300-01, quotes similar remarks by Gance in an interview (Cinemonde, 17 June 1937) and in his official written announcement of the film.

45. Rondel Collection, Bibliothèque de l'Arsenal, Paris, France, $4^{\circ}$ Rk. 5395, BRO 00006, 4.

46. Rondel Collection, Bibliothèque de l'Arsenal, Paris, France, $4^{\circ}$ Rk. 5395, BRO 00006, 1. See also the documents reproduced in Icart, 303.

47. Cf. King, 139.

48. Rondel Collection, Bibliothèque de l'Arsenal, $4^{\circ}$ Rk. 5395, BRO 00006, 8-9.

49. On the notion of la guerre franco-française and the struggle between French right and left from the 1930s through the Liberation, see Henry Rousso, Le syndrome de Vichy: de 1944 a nos jours, $2^{\text {nd }}$ ed. (Paris: Seuil, 1990).

50. On Taittinger, La Rocque, interwar French fascism, and 6 February 1934, see Robert Soucy, French Fascism: The First Wave, 1924-1933 (New Haven, Yale UP, 1986) and French Fascism: The Second Wave, 1933-1939 (New Haven: Yale UP, 1995).

51. King, 144.

52. Icart, 203-09; King, 164.

53. See King, 169-178; Icart, 311-33.

54. King, 168

55. For the history of the Douaumont monument, I rely on Antoine Prost, "Verdun," in Pierre Nora, ed., Les lieux de la mémoire, vol. 3, La nation (Paris: Gallimard, 1986), tome 2, 124.

56. Prost, Les anciens combattants, 1: 181.

57. Prost, Les anciens combattants, 1: 182.

58. Icart, 283.

59. King, 140

60. Norman Ingram, The Politics of Dissent: Pacifism in France, 1919-1939 (Oxford: Clarendon Press, 1991), 2.

61. Ingram, 9, see also 237-240. For a broad survey of "la droite de Munich," see Jean Defrasne, Le pacifisme en France (Paris: Presses Universitaires de France, 1994), 165-77.

62. Ingram, 23, 103.

63. Ingram, 42-5.

64. Icart, 102.

65. Icart, 106-7.

66. Weber, 11-25. 22.

67. Ingram 83-4. On the tenets of integral pacifism, see Ingram $20,56,71-6,109,135-6,219$

68. Ingram, $93,100$. 
69. Ingram, 109; see also 112-113, 121.

70. Alain, "Le droit par la paix," Propos, ed. M. Savin and Samuel S. de Sacy, Plēiade (Paris: Gallimard, 1956, 1970), 1: 483-5, qtd. in Andre Sernin, Alain, un sage dans la cite, 1868-1951 (Paris: Laffont, 1985), 238.

71. Ingram, 69-83, gives a succinct but detailed account of Challaye and Emery's role in the split between the APD and integral pacifism. For an overview of splinter pacifist groups in the 1930s, see also Defrasne, 138-151. The February and April 1932 issues of Libres propos, the periodical published by Alain's circle of friends, feature a debate between Ruyssen, Challaye, and Alain's unofficial spokesperson, Georges Canguilhem, over the direction pacifism should take (Sernin, 301). According to Sernin, 349-50, Emery published an essay on disarmament and the revision of WWI treaties in the 31 May 1935 issue of Libres propos.

72. Ingram, 122-3.

73. Ingram, 127.

74. On the LICP, see also Ingram, 134-178.

75. Ingram, 128, 140-1, 154-5.

76. Weber, 19.

77. Roger Martin du Gard, Correspondance générale, vol. 6, ed. Pierre Bardel and Maurice Rieuneau (Paris: Gallimard, 1980), letter dated 17 April 1936 to Simon and Dorothy Bussy, 504; letter dated 16 May 1936 to Marcel Lallemand, 514. On Martin du Gard's fervent respect for Alain, see Sernin, 232-3, 371, 381. On a different note, Jacques's actions do show the importance interwar integral pacifism attached to conscientious objection. Ingram, 167, remarks France's lack of a tradition of conscientious objection and notes the LICP's claim that if the nation mobilized in 1933, up to 300,000 French would refuse to report.

78. Ingram, 145.

79. Ingram, 146, quoting Méric in La patrie humaine, 16-23 April 1932, 6. On the 1928 showing of the silent $J$ 'accuse, see Abel, 267.

80. Norman, 149, 157.

81. Prost, Les anciens combattants, $1: 110$.

82. Ingram, 126-7.

83. Ingram, 182; Prost, Les anciens combattants, 1: 178.

84. Ingram, 185; see also 188-9.

85. Norman, 201-3, 207.

86. “Au travail, pour la paix des peuples!," Le barrage, 6 October 1938, 1, qtd. by Ingram, 232.

87. Ingram, 242.

88. For Alain, in addition to Sernin and Defrasne, see Gisele and Serge Bernstein, Dictionnaire historique de la France contemporaine, (Brussels: Editions Complexe, 1990), 1: 13-15; D. J. Fisher, "Alain," Biographical Dictionary of Modern Peace Leaders, ed. H. Josephson et al (Westport, CT: Greenwood Press, 1985), 8-11. Days after Hitler invaded France, Alain and other pacifists sponsored a petition, entitled "Paix immediate!," which demanded France halt the war. Alain denied he actually signed the petition when French authorities brought pressure to bear on what could be seen as an act inciting soldiers to disobedience (see Sernin, 404-410).

89. King, 124.

90. Sernin, 325-6.

91. For Alain's emphasis on the internal fight against the French extreme right, in distinction to German and Italian fascisms, see Sernin, 301, 326.

92. Alain, Propos, 2: 1125.

93. See also, among many other essays, "Dire non," Mars ou La guerre jugé, 256-288.

94. See also Alain, "Savoir ce qu'on veut," Mars, 280-3.

95. See also 130. Alain's notion that war is a mystification derived from unbridled passions, and that it depends on individual choice and is never truly inevitable, predates his participation in WWI. See Propos, 2: 318-19, the essay dated 12 August 1913.

96. See also 212.

97. King, 164. 
98. On the French empire and Tavernier's use of Vietnamese, Maghrebian, and Senegalese troops to represent a flawed process of grieving in La vie et rien d'autre, see Padivong Norindr, "Mourning, Memorials, and Filmic Traces: Reinscribing the Corps étrangers and Unknown Soldiers in Bertrand Tavernier's Films," Studies in Twentieth-Century Literature 23.1 (1999), 116-141.

99. "Cosmos scénariste," 7. 116.

100. "La vie et rien d'autre. Découpage ... après montage," L'avant-scéne CINEMA, no. 388,

101. Winter, 90-1, 119.

102. My thanks to Mary Byrd Kelly, for pointing out the "crosses" in the closing shot of La vie et rien d'autre.

103. Rondel Collection, Bibliothèque de 1'Arsenal, France, $4^{\circ}$ Rk. 5395, Pathè Frères advertisement, message from Gance to the public.

104. The research for this article was funded by the Graduate Research Fund, University of Kansas. 